\title{
Textile Wastewater Treatment Using Biogranules Under Intermittent Anaerobic/Aerobic Reaction Phase
}

\author{
Khalida MUDA*, Azmi ARIS*, Mohd Razman SALIM*, Zaharah IBRAHIM**, Adibah \\ YAHYA** \\ *Faculty of Civil Engineering, Department of Environmental Engineering, Universiti Teknologi \\ Malaysia, 81310, Skudai, Johor, Malaysia \\ **Faculty of Biosciences and Bioengineering, Department of Biological Sciences, Universiti \\ Teknologi Malaysia, 81310, Skudai, Johor, Malaysia
}

\begin{abstract}
Granular sludge was successfully cultivated under intermittent anaerobic and aerobic reaction phase strategy using synthetic textile wastewater for 72 days. The granules were developed under superficial air velocity of $2.4 \mathrm{~cm} / \mathrm{s}$ in the SBR system that operated at hydraulic retention time of 8 hours. The unique feature of the granules is that they were cultivated using anaerobic granules as seeding material. The microscopic examination showed clear, smooth and spherical shape of mature granules with diameters ranging from 0.85 to $1 \mathrm{~mm}$ after 60 days of operation. The particle size distribution has shifted from less than $0.3 \mathrm{~mm}$ in the beginning to about $1 \mathrm{~mm}$ with some reaching $2.5 \mathrm{~mm}$. The granules had good settling properties indicated by their high settling velocity reaching up to about $42 \mathrm{~m} / \mathrm{h}$ and low sludge volume index (SVI) of $61 \mathrm{~mL} / \mathrm{g}$. The MLSS has also increased from $4.8 \mathrm{~g} / \mathrm{L}$ to $7 \mathrm{~g} / \mathrm{L}$ while the granular strength has also increased with time. During the development process, the granular sludge system was capable of treating synthetic textile dyeing wastewater containing mixed dyes with $93 \%$ of COD and ammonia removal and $56 \%$ of color removal.
\end{abstract}

Keyword: color, granular sludge, intermittent, mixed dyes, sequential batch reactor

\section{INTRODUCTION}

Granular sludge is a microbial aggregate that consist of high concentration selfimmobilized microorganisms. The system, which could be either in the form of anaerobic or aerobic granules, offers several advantages over conventional activated sludge flocs. This includes strong and compact microbial organization with excellent settling properties (Liu and Tay, 2004). With such characteristics, the granular sludge system is able to retain high concentration of biomass within the reactor and able to withstand higher organic loadings (Chen et al., 2008). The granular sludge system can be considered as an extension of biofilm growth system (Linlin et al., 2005).

Studies on the anaerobic granular sludge system have been well documented for the past twenty years (Liu and Tay, 2004). However, due to the long start-up period for the formation of the anaerobic granules, more attention has been devoted to the application of aerobic granules. Different types of bacteria such as acidifying bacteria (Lens et al., 2003), autotroph nitrifying bacteria (Shi et al., 2010), denitrifying bacteria and aerobic heterotrophs (Eiroa et al., 2004) have been used in cultivating the microbial granular sludge. Aerobic granule technology has been applied for treating different types of contaminants such as nitrogen, chloroaniline, high strength phenol and phosphorus (Qin and Liu, 2006; Zhu et al., 2007; Ho et al., 2010; Wu et al., 2010). 
Complete degradation of dyestuff in textile wastewater requires both anaerobic and aerobic treatment (van der Zee and Villaverde, 2005). Degradation under anaerobic process causes the cleavage of the $\mathrm{N}=\mathrm{N}$ bond that resulted with removal of color of the wastewater. At this stage, stable biotransformation byproduct, namely amines will be produced (Goncalves et al., 2005; Franciscon et al., 2009). Since amines are considered as toxic compounds and could not be degraded under anaerobic condition, further aerobic degradation is required to transform amines to simpler compounds (Ong et al., 2008).

While many studies have reported the applications of anaerobic granules in treating textile wastewater (Baêta et al., 2011; Rongrong et al., 2011; Ong et al., 2012), the use of aerobic granules under intermittent anaerobic and aerobic treatment phases for the same purpose appears to be lacking. Furthermore, when a conventional sequential anaerobic and aerobic treatment process was employed, two reactors were normally used to fulfill the different oxygen requirements of the process (Moosvi and Madamwar, 2007; Isik and Sponza, 2008; Elbanna et al., 2010). This adds up to the cost of the reactor set-up and requires bigger working area. The application of granular sludge in a single reactor column with intermittent anaerobic and aerobic reaction phase provides a more economical approach for treating textile wastewater.

Our initial study on the development of biogranules and its application in treating textile wastewater under sequential anaerobic and aerobic phases has been reported in Muda et al. (2010). This paper reports the results of further study conducted under different operating conditions (i.e. hydraulic retention time, superficial air velocity, size and working volume of the reactor, and organic loading rate). The characteristics of the biogranules throughout the development period are presented along with the performance of the system in treating the textile wastewater.

\section{MATERIALS AND METHODS Wastewater composition}

The composition of synthetic wastewater and trace elements were prepared according to Muda et al. (2010), Beun et al. (1999) and Smolder et al. (1995), respectively. The synthetic textile feed comprised of $0.75 \mathrm{~g} / \mathrm{L}$ glucose, $0.75 \mathrm{~g} / \mathrm{L}$ sodium acetate, $0.125 \mathrm{~g} / \mathrm{L}$ ethanol (Muda et al., 2010), $0.16 \mathrm{~g} / \mathrm{L} \mathrm{NH} 4 \mathrm{Cl}, 0.23 \mathrm{~g} / \mathrm{L} \mathrm{KH}_{2} \mathrm{PO}_{4}, 0.58 \mathrm{~g} / \mathrm{L} \mathrm{K}_{2} \mathrm{HPO}_{4}, 0.07$ $\mathrm{g} / \mathrm{L} \mathrm{CaCI} \cdot 2 \mathrm{H}_{2} \mathrm{O}, 0.09 \mathrm{~g} / \mathrm{L} \mathrm{MgSO}_{4} \cdot 7 \mathrm{H}_{2} \mathrm{O}, 0.02 \mathrm{~g} / \mathrm{L}$ EDTA (Beun et al., 1999). The compositions of trace element were $0.15 \mathrm{~g} / \mathrm{L} \mathrm{H}_{3} \mathrm{BO}_{3}, 1.5 \mathrm{~g} / \mathrm{L} \mathrm{FeCl}_{3} \cdot 4 \mathrm{H}_{2} \mathrm{O}, 0.12 \mathrm{~g} / \mathrm{L}$ $\mathrm{ZnCl}_{2}, 0.12 \mathrm{~g} / \mathrm{L} \mathrm{MnCl} \cdot 4 \mathrm{H}_{2} \mathrm{O}, 0.03 \mathrm{~g} / \mathrm{L} \mathrm{CuCl}_{2} \cdot 2 \mathrm{H}_{2} \mathrm{O}, 0.06 \mathrm{~g} / \mathrm{L} \mathrm{NaMoO}_{4} \cdot 2 \mathrm{H}_{2} \mathrm{O}, 0.15 \mathrm{~g} / \mathrm{L}$ $\mathrm{CoCl}_{2} \cdot 6 \mathrm{H}_{2} \mathrm{O}, 0.03 \mathrm{~g} / \mathrm{L} \mathrm{CoCl} 2 \cdot 6 \mathrm{H}_{2} \mathrm{O}$ (Smolder et al., 1995). The dyes used in this study were Sumifix Black EXA, Sumifix Navy Blue EXF (Sumika Chemtex, Japan) and Synozol Red K-4B (Kisco Kapilion, Korea) in equal mass proportion. The total dye concentration in the synthetic wastewater was $50 \mathrm{mg} / \mathrm{L}$. The mixture gave an initial COD, color and ammonia concentrations of 1,240 mg/L, 1,020 ADMI (America Dye Manufacturing Index) and $29 \mathrm{mg} / \mathrm{L}$, respectively. The initial $\mathrm{pH}$ of the synthetic wastewater was adjusted to $7.0 \pm 0.5$. 


\section{Reactor set-up}

The design of the reactor system was based on Wang et al. (2004) and Zheng et al. (2005) with several modifications. A reactor column was designed with internal diameter of $5 \mathrm{~cm}$ and total height of $100 \mathrm{~cm}$. The reactor is designed to work with $1.5 \mathrm{~L}$ of total working volume in batch mode. The system is operated with volumetric exchange rate (VER) of 50\%. Aerobic condition in the reaction stage is achieved via aeration through a fine air bubble diffuser located at the bottom of the column. Anaerobic condition was achieved naturally without the use of $\mathrm{N}_{2}$ purging.

\section{Analytical methods}

The observation of the morphological and structural features of the granules was carried out using scanning electronic microscope (FESEM-Zeiss Supra 35 VPFESEM, USA) and stereo microscope equipped with digital image management and image analysis Paxcam, USA (Version 6). The granules were left dried at room temperature prior to gold sputter coating (Bio Rad Polaron Division SEM Coating System, USA) for $45 \mathrm{~s}$ at $20 \mathrm{mM}$ coating current. Physical parameters such as settling velocity, sludge volume index (SVI), mixed liquor suspended solid (MLSS), mixed liquor volatile suspended solid (MLVSS) and chemical parameters including COD, color and $\mathrm{NH}_{3}$ were analyzed according to Standard Methods (APHA, 1995). Determination of the granules' strength was based on Ghangrekar et al. (2005). The granular size distributions were measured throughout the experiment using sieves analysis. The volume of each different granular size was expressed as a fraction of total volume of granule.

\section{Experimental procedures}

Sludge from a sewage treatment plant and sludge from a textile wastewater treatment plant were used for the granules development. The sludge was sieved with a mesh of 1.0 $\mathrm{mm}$ to remove debris and inert impurities prior to use. Equal volume of sludge from both sources were mixed and the sludge mixture was acclimatized with dye degrader microbes (Ibrahim et al., 2009) for 2 months. Additionally, anaerobic granules (MLSS of $3.3 \mathrm{~g} / \mathrm{L}$ and size less than $1 \mathrm{~mm}$ ) were obtained from an upflow anaerobic sludge blanket (UASB) reactor system treating paper mill industrial effluent and used as seed.

The experiment started with the addition of $750 \mathrm{~mL}$ of the acclimatized mixed sludge, $750 \mathrm{~mL}$ of synthetic textile wastewater and $150 \mathrm{~mL}$ of anaerobic granules into the reactor column giving total sludge concentration of $4.78 \mathrm{~g} / \mathrm{L}$ and substrate loading rate of $2.48 \mathrm{~kg} \mathrm{COD} /\left(\mathrm{m}^{3} \cdot \mathrm{d}\right)$. The reactor was operated in successive cycles of 8 hours, comprised of $5 \mathrm{~min}$ fill, $460 \mathrm{~min}$ reaction, $5 \mathrm{~min}$ settle, $5 \mathrm{~min}$ decant and 5 min idle. The reaction mode consists of $230 \mathrm{~min}$ of anaerobic and $230 \mathrm{~min}$ of aerobic phases. The DO concentration during the anaerobic phase was less than $1 \mathrm{mg} / \mathrm{L}$ and reached saturation concentration during the aerobic phase. The superficial air velocity during the aerobic phase was $2.4 \mathrm{~cm} / \mathrm{s}$. The $\mathrm{pH}$ during the reaction process was in the range of 6.0 to 7.5 and the experiment was carried out at room temperature of about $28^{\circ} \mathrm{C}$. The experiment was carried out for a period of 72 days. Within this period, no excess sludge was removed from the reactor. Samples of $20 \mathrm{~mL}$ were taken twice a day from the influent and effluent tanks and were analyzed for COD, ammonia and color removal. 


\section{RESULTS}

\section{Granule Development}

The microscopic view of the granules development from seed sludge to the formation of matured granule is illustrated in Fig. 1. Figure 1a shows that the seed sludge was irregular in shape and dominated by filamentous microorganisms. Fig. 1b shows the sludge particles during the start-up period. During this stage, several factors such as hydrodynamic forces, diffusion of substrates, gravitational and thermodynamic forces and cell mobility may influence the initial aggregation of the particles (Liu and Tay, 2002). Within 2 weeks, the small particles manage to form floc-like sludge aggregates as shown in Fig. 1c. These flocs were very soft and easily fragmented when exposed to high shear force imposed during the aeration phase. At this stage, smaller and lighter fractions were observed to be washed out during the decanting phase and removed from the reactor. The remaining sludge flocs became the precursors for the granule formation. These phenomena were also observed by Beun et al. (1999). They hypothesized the fragmentation to be caused by diffusion limitation of oxygen into the granules inner part.
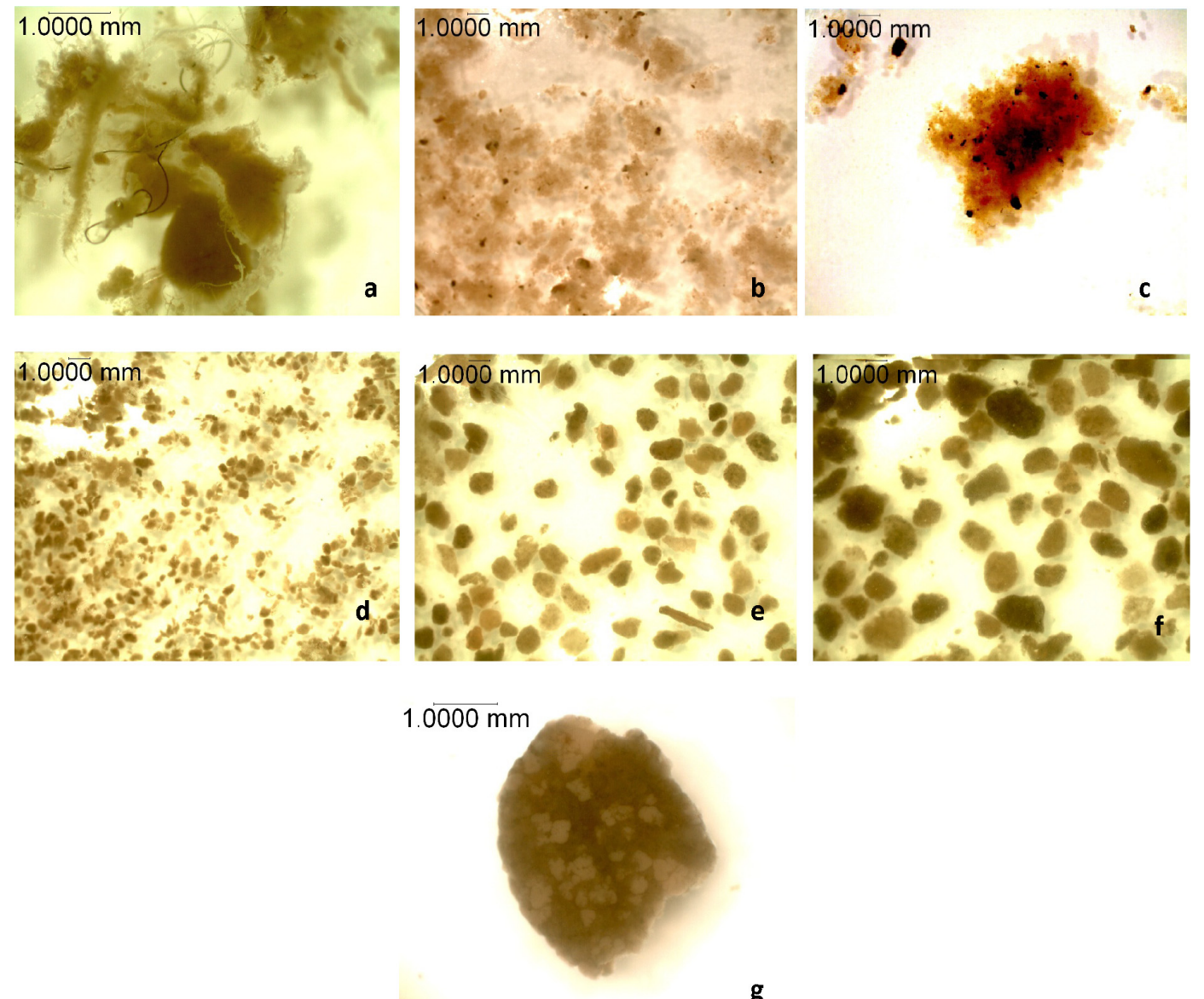

g

Fig. 1 - The morphological development of aerobic granule seeded from anaerobic granular sludge (scale bar at steady-state equals to $0.5 \mathrm{~mm}$ ). Using stereo microscope, Photo (a) and (g) were taken with magnification of $20 \mathrm{X}$ while Photo (b) to (f) were taken with magnification of 6.3X. (a) Filamentous bacteria dominating the reactor system, (b) Sludge particles during the startup of experiment. (c) Sludge flocs after 14 days, (d) Granules after 35 days, (e) Granules after 45 days, (f) Granules after 60 days, (g) Matured granules after 68 days. 
As shown in Fig. 1d, more bacteria cells grew on the precursor and after 35 days of development, irregular and soft granules started to appear in the reactor. At this stage, the average diameter of the granules was $0.45 \mathrm{~mm}$. After 45 days, the granules increased to an average size of $0.9 \mathrm{~mm}$ (Fig. 1e) and after 60 days, the irregular granules have turned into smoother and rounder (Fig. 1f). The average size of the granules has grown to $1.5 \mathrm{~mm}$ after 68 days of development and at this stage, granules with size up to 2.5 $\mathrm{mm}$ were also detected in the reactor (Fig. 1g).

During the initial stage, the anaerobic granules that were used as seed in the granulation process have changed in color from black to grey before disintegrating into smaller fragments as they were exposed to aeration. Some of the small fragments were removed along with the effluent but bigger fragments remained in the reactor and served as the precursors for the formation of the microbial granule. Fig. $1 \mathrm{~g}$ shows the granule that was formed from the patches of anaerobic granule.

The detailed microstructure of the granules was observed using scanning electron microscopy and is shown in Fig. 2. Figures $2 \mathrm{a}$ and $2 \mathrm{~b}$ show that the surface structure of the aerobic granules consist of rods and cocoids shaped arrangement that are made-up
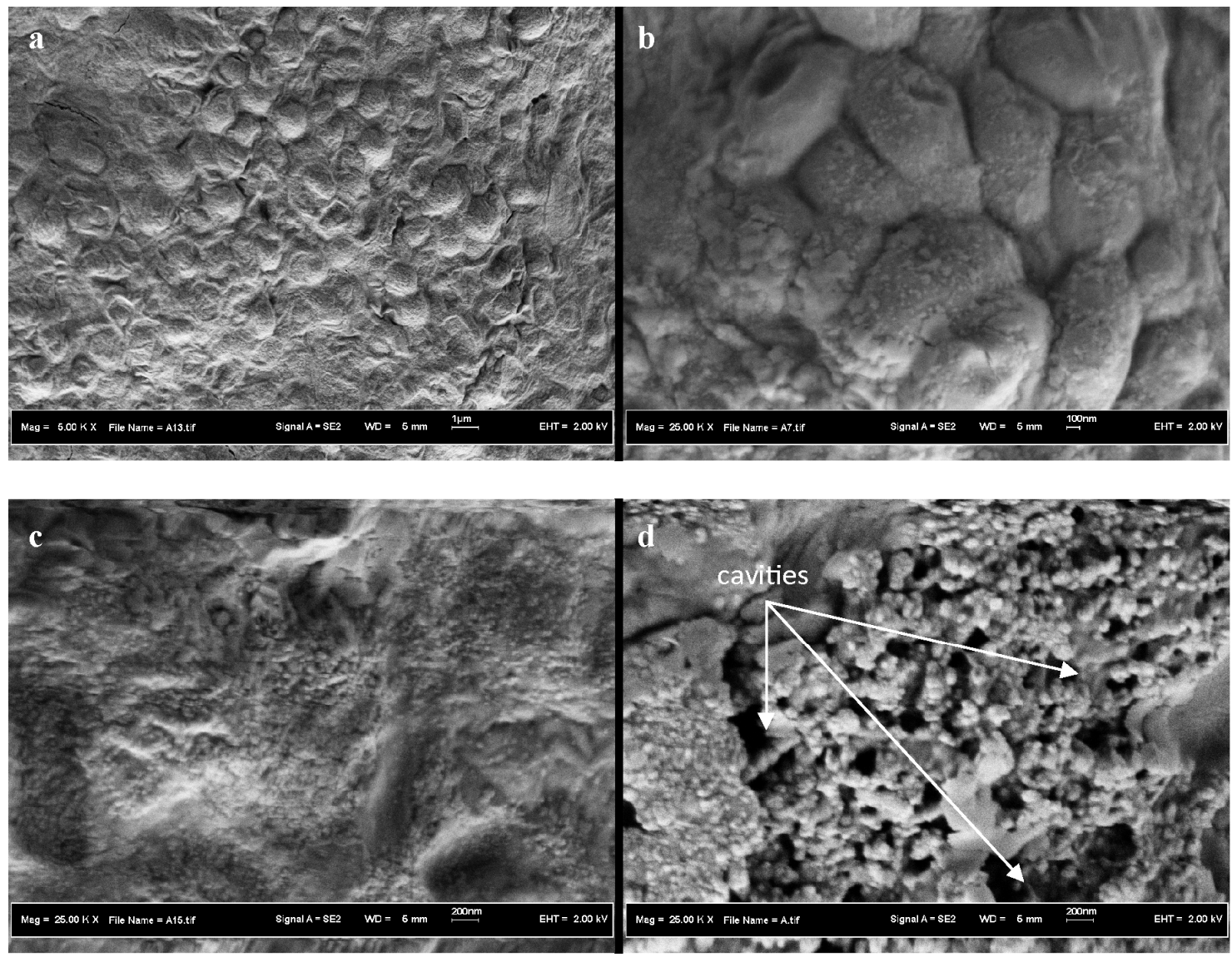

Fig. 2 - SEM microstructure observation on matured granular sludge. (a) Coccoid (magnification 5,000K) and (b) rod shape (magnification 25,000K) arrangement of bacteria tightly linked to one another. (c) Bacterial on the surface of the granule, (d) Cavities that present between bacteria clumped inside the granule (magnification 25,000K). 
of thousands of bacteria clumped together in the presence of EPS. Weber et al. (2007) reported that the production of extracellular polysaccharides (EPS) mediates both the cohesion and adhesion within the immobilized cells community resulted in strong, dense and compact granular structure. Figure $2 \mathrm{c}$ shows the presence of cocoids bacteria spread over the surface of the granule while Fig. $2 \mathrm{~d}$ demonstrates the inner structure of the clumps. The inner structure also consists of cavities between the bunch of bacteria, which act as passages that allow the movement of nutrient and waste products into and out of the granules.

\section{Characteristics of the Microbial Granule}

The characteristics of the initial mixed sludge and the granules developed in the reactor after 60 days of operation were determined and compared (Table 1). The initial mixed sludge used in this study had diameters ranging from 0.01 to $0.05 \mathrm{~mm}$. After 60 days of development, the average diameter of the granules had increased to about $0.9 \mathrm{~mm}$.

The average settling velocity of the initial mixed sludge was about $10 \mathrm{~m} / \mathrm{h}$. The matured granules had a settling velocity in the range of 38.5 to $61.4 \mathrm{~m} / \mathrm{h}$ with an average of about $42 \mathrm{~m} / \mathrm{h}$, showing a significant improvement of the settling property. The average settling velocity of the granules in this study is four times higher as compared to the activated sludge flocs reported by Tay et al. (2002), i.e. less than $10 \mathrm{~m} / \mathrm{h}$. Additionally, the granule settling velocity from this work is almost two times higher than the settling velocity of the aerobic granules reported by Jang et al. (2003). The higher settling velocity of the granules developed in this study may be due to the use of anaerobic granules as seeding in the granulation process. However, further detailed studies are needed to verify this assumption.

The SVI of the initial mixed sludge used in this study was $218 \mathrm{~mL} / \mathrm{g}$, which agrees with the values reported by Tchobanoglous et al. (2004) for activated sludge flocs. The high SVI value is mainly caused by the presence of filamentous microorganisms as shown in Fig. 1a. Since fluffy filamentous microorganisms in the seed sludge have very low settling velocity, they were flushed out due to the short settling time (i.e. 5 min) applied in the settling phase. After almost 35 days, the SVI value decreased to $62 \mathrm{~mL} / \mathrm{g}$ indicating good settling property of the biomass along with the formation of the granules as observed in Fig. 1. Figure 3 shows the change in settling velocity and SVI of the biomass throughout the experiment.

Table 1 - Characteristics of the initial mixed sludge and granular sludge.

\begin{tabular}{|c|c|c|}
\hline Property & Initial mixed sludge $^{\mathrm{a}}$ & Granular sludge \\
\hline Average particle diameter $(\mathrm{mm})$ & 0.02 & 0.9 \\
\hline Average settling velocity $(\mathrm{m} / \mathrm{h})$ & 10 & 42 \\
\hline $\mathrm{SVI}(\mathrm{mL} / \mathrm{g})$ & 218 & 61 \\
\hline $\operatorname{MLSS}(\mathrm{g} / \mathrm{L})$ & 1.4 & 7.0 \\
\hline MLVSS/MLSS (\%) & 69 & 84 \\
\hline Granular strength $^{\mathrm{b}}$ & 84 & 11 \\
\hline
\end{tabular}


Figure 4 shows the changes of the granular strength (expressed as integrity coefficient, IC) of the granules throughout their development stage. Lower value of IC indicates higher granular strength of the granules. As shown in the figure, the granular strength increases with time, along with the development of the granules. High superficial air velocity $(2.4 \mathrm{~cm} / \mathrm{s})$ applied in this study is anticipated to facilitate the aggregation of the microorganisms within the reactor system and resulted with higher granular strength (Chen et al., 2007).

\section{Particle Size Distribution}

The particle size distribution in the reactor as a function of time was monitored and is presented in Fig. 5. The size distributions of the granules are compared from day 1, 14, 35 and 68 days of the operational period.

The particle size distribution was measured based on the volume percentage of the sieved granule. As shown in Fig. 5, the particle size increases gradually during the development period, which indicates gradual process of microbial granular sludge

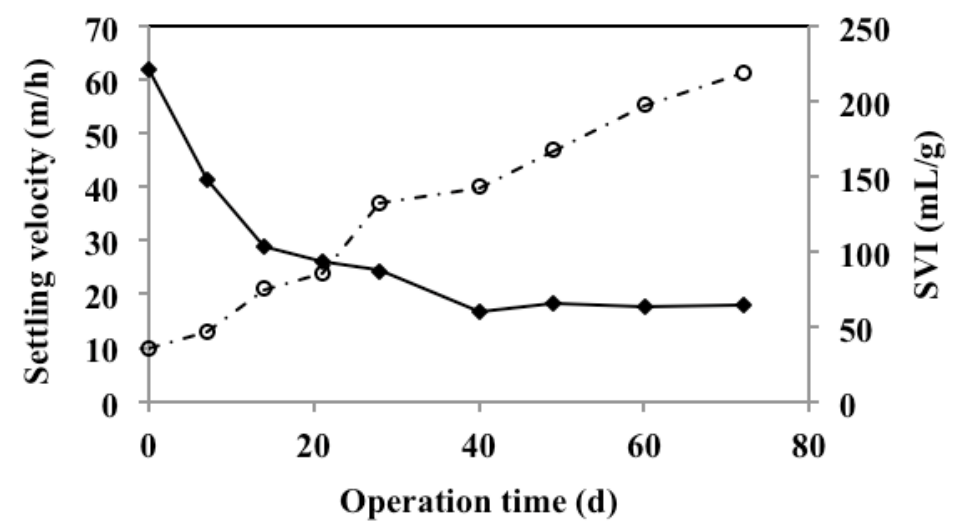

Fig. 3 - SVI and settling velocity profile of the SBR system.

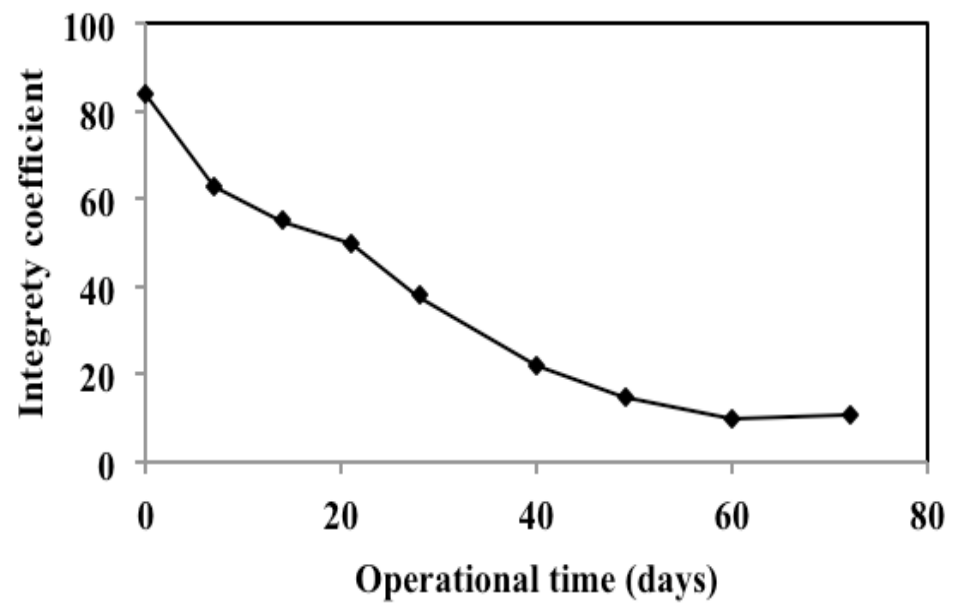

Fig. 4 - The profile of integrity coefficient of the microbial granular biomass (lower IC indicates higher granular strength).

formation. On the first day, the average size for most of the biomass was less than 0.3 
$\mathrm{mm}$. After 14 days, the particle size distribution shifted to sizes of more than $0.3 \mathrm{~mm}$. On the $35^{\text {th }}$ day, the percentage of particles with size less than $0.3 \mathrm{~mm}$ decreased while bigger size particles were observed. On the last day of the experiment, the particles of less than $0.3 \mathrm{~mm}$ were completely disappeared while majority of the particles were in the range $0.85-1 \mathrm{~mm}$ with more than $20 \%$ of them greater than $1 \mathrm{~mm}$. At this stage, the size of some particles reached $2.5 \mathrm{~mm}$.

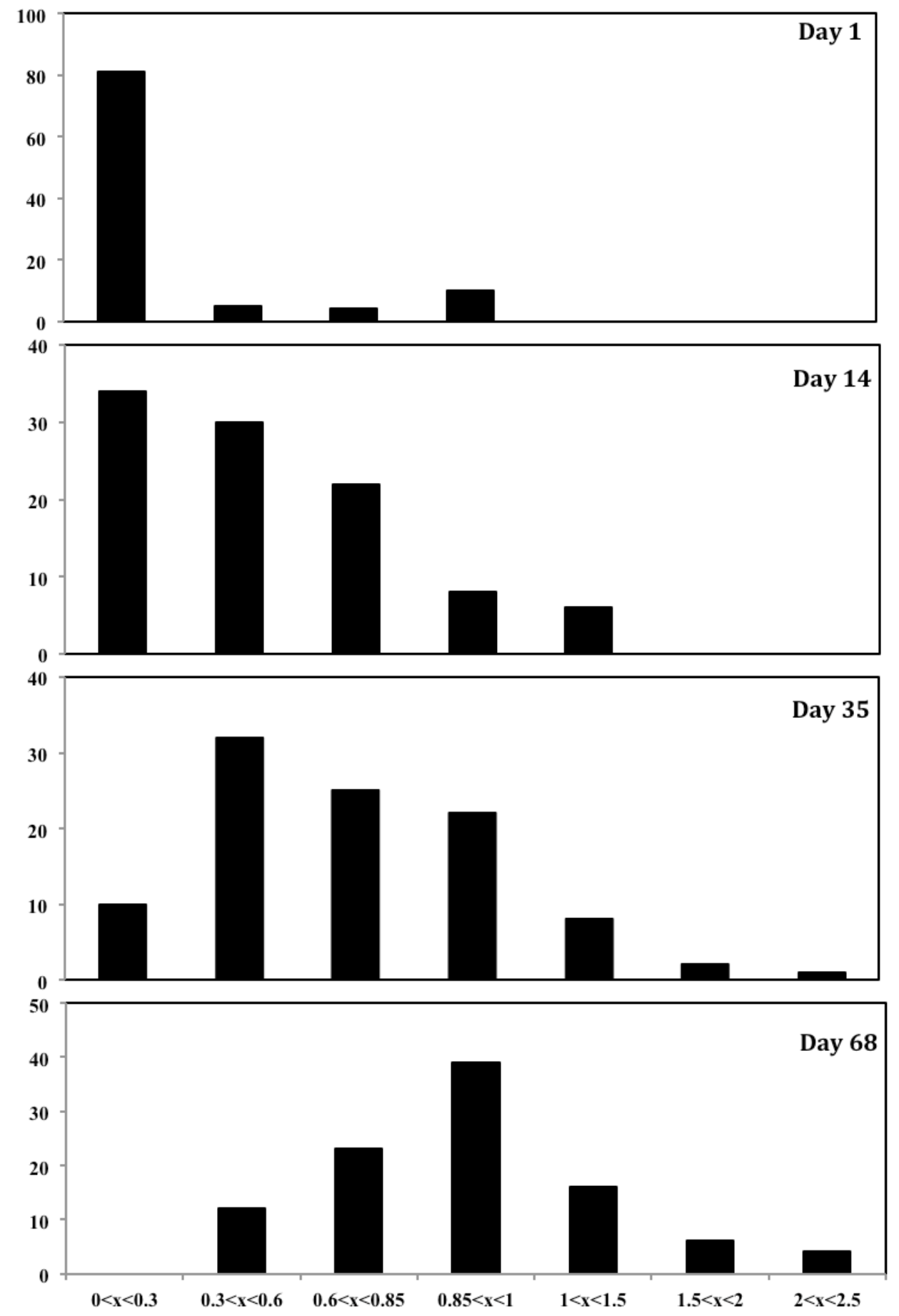

Fig. 5 - Particle size distributions. 


\section{Biomass Profile}

Figure 6 illustrates the change of biomass concentration (MLSS) in the reactor throughout the experiment. High sludge washout reducing the biomass concentration from $4.78 \mathrm{~g} / \mathrm{L}$ to $3.14 \mathrm{~g} / \mathrm{L}$ during the initial stage was due the short settling time set in the experiment. However, with time, the biomass concentration in the reactor gradually increased and reached almost $7 \mathrm{~g} / \mathrm{L}$ of MLSS. The MLVSS also shows a similar pattern to MLSS but at a lower concentration. The increase in MLSS and MLVSS shows a good accumulation of biomass in the reactor. This is expected to be due to the increase in settling velocity of the granules as they were developed. This resulted with more biomass being able to settle, hence, retained in the reactor.

The initial ratio of MLVSS to MLSS of the initial mixed sludge was $69 \%$ and increased to $84 \%$ at the end of the experiment. The high MLVSS/MLSS ratio indicates the high concentration of microorganisms within the reactor system.

\section{Removal Efficiency}

Figure 7 illustrates the removal profile of COD, ammonia and color during the granules development process. Figures $7 \mathrm{a}$ and $7 \mathrm{~b}$ show almost the same pattern of COD and ammonia removal. At the initial stage, the removal efficiency of COD, and ammonia were $76 \%$ and $60 \%$, respectively. The removal percentage increased with time and reached a maximum of $93 \%$ for both COD and ammonia after 72 days. With higher biomass concentration in the reactor, more degradation activities took place in the reactor and thus, improve the performance of the system.

Figure $7 \mathrm{c}$ shows the profile of color removal throughout the development of the granules. During the initial stage, the removal percentage for color was $36 \%$ and increased to $55 \%$ at the end of the experiment. Throughout the development period, the removal of color was much lower as compared to COD and ammonia. The low percentage of color removal obtained in this study may indicate that the 8 hours HRT is not enough to provide higher removal. As the reaction phase was divided into anaerobic and aerobic phases, the actual HRT required for color removal to occur (i.e. anaerobic phase) was only about 4 hours, which may be too short for the dye degradation to occur.

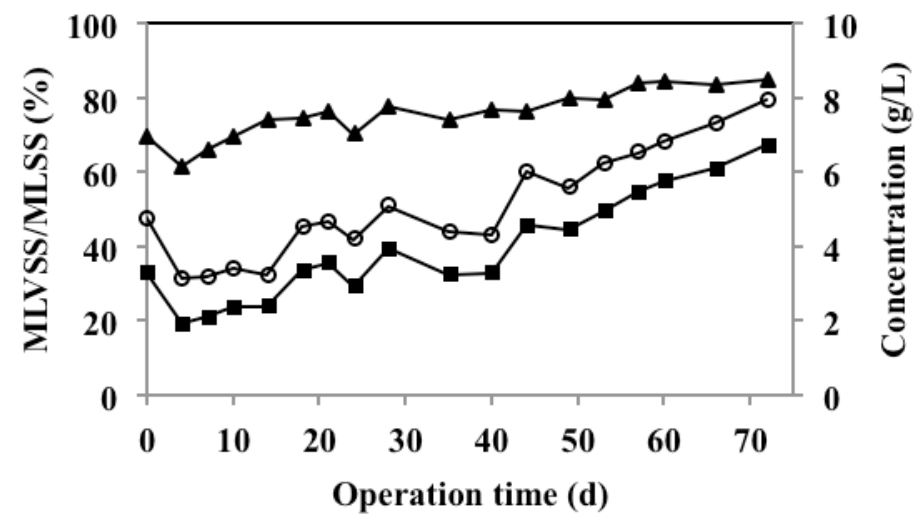

Fig. 6 - Performance of the biomass concentration for the continuous operation of SBR system for the MLSS (O). MLVSS ( $\bullet$ ) and the ratio of MLVSS/MLSS

$(\boldsymbol{\Delta})$. 


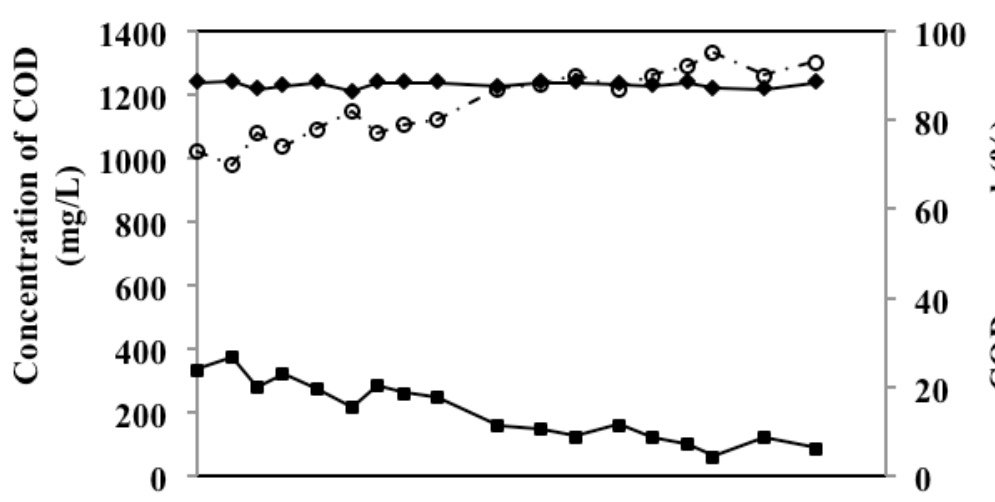

导
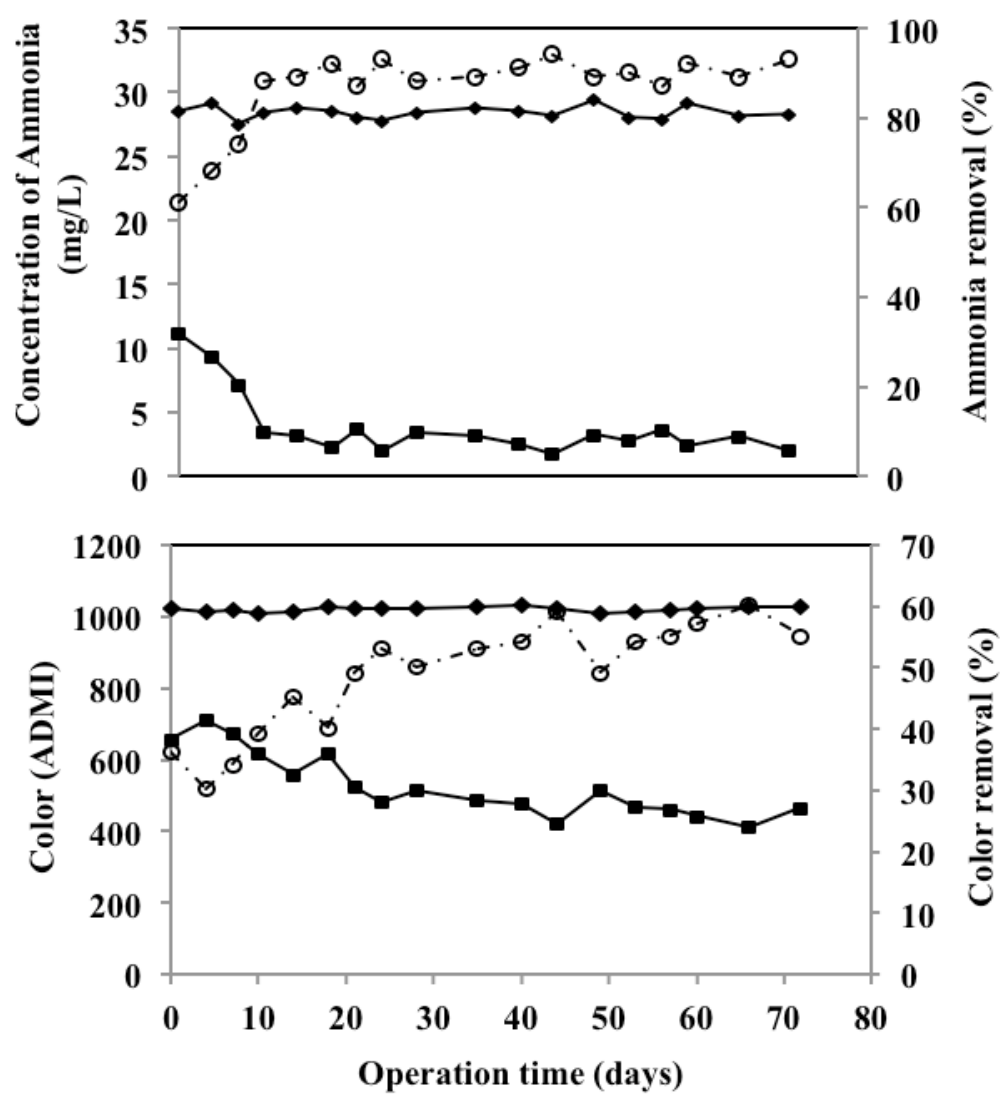

Fig. 7 - Removal performance for continuous operation of SBR reactor of (a) COD, (b) ammonia and (c) color. ( $\diamond$ Influent; ( ) Effluent; ( $\bigcirc)$ Removal percentage .

Longer HRT, especially on the anaerobic phase is normally required for better color removal (Isik and Sponza, 2008). Furthermore, it was also anticipated that the exposure of amines, the byproduct of dye degradation, to oxygen during aerobic reaction phase, could cause the wastewater to be colored again and hence, causing reduction in the total color removal efficiency. 


\section{CONCLUSIONS}

Microbial granules sludge developed with anaerobic granules as seed, exhibited different morphology features, improved settling properties (i.e. $42 \mathrm{~m} / \mathrm{h}$ ) and stronger granular structure as compared to the aerobic granules commonly developed from conventional activated sludge. Due to the improved settling ability of the developed granules, the concentration of biomass in the reactor has significantly increased at the end of the development process. The size of the biomass particles increased throughout the development process indicating the formation of the granules with increasing particle size from an average value of less than $0.3 \mathrm{~mm}$ to about $1 \mathrm{~mm}$. Some of the granules have reached up to $2.5 \mathrm{~mm}$. The developed granular biomass shows high removal efficiency for COD and ammonia and moderate color removal. With further studies, the developed granule can be used for dye degradation process using intermittent anaerobic and aerobic reaction phase strategy with longer HRT.

\section{ACKNOWLEDGEMENTS}

The authors wish to thank the Ministry of Science, Technology and Innovation (MOSTI), Ministry of High Education (MOHE) and Universiti Teknologi Malaysia for the financial supports of this research (Grants No.: 79137, 78211 and 75221)

\section{REFERENCES}

APHA-AWWA-WEF (1995) Standard methods for the examination of water and wastewater, 20th ed., American Public Health Association/American Water Works Association/Water Environment Federation, New York, USA.

Baêta B. E. L., Aquino S. F., Silva S. Q. and Rabelo C. A. (2012) Anaerobic degradation of azo dye Drimaren blue HFRL in UASB reactor in the presence of yeast extract a source of carbon and redox mediator. Biodegradation, 23(2), 199-208.

Beun J. J., Hendricks A., van Loosdrecht M. C. M., Morgenroth E., Wilderer P. A. and Heijnen J. J. (1999) Aerobic granulation in a sequencing batch reactor. Wat. Res., 33, 2283-2290.

Chen Y., Jiang W., Liang D. T. and Tay J. H. (2007) Structure and stability of aerobic granules cultivated under different shear force in sequencing batch reactors. Appl. Microbiol. and Biotechnol., 76, 1199-1208.

Chen Y., Jiang W. J., Liang D. T. and Tay J. H. (2008) Biodegradation and kinetics of aerobic granules under high organic loading rates in sequencing batch reactor. Appl. Microbiol. and Biotechnol., 79, 301-308.

Eiroa M., Kennes C. and Veiga M. C. (2004) Formaldehyde and urea removal in a denitrifying granular sludge blanket reactor. Wat. Res., 38, 3495-3502.

Elbanna K., Hassan G., Khider M. and Mandour R. (2010) Safe biodegradation of textile Azo dyes by newly isolated lactic acid bacteria and detection of plasmids associated with degradation. J. of Bioremed. and Biodegrad., DOI: 10.4172/21556199.1000110.

Franciscon E., Zille A., Garboggini F. F., Silva I. S., Paulo A. C. and Durrant L. G. (2009) Microaerophilic-aerobic sequential decolourization/biodegradation of textile Azo dyes by a facultative Klebsiella sp. Strain VN-31. Proc. Biochem., 44, 446-452. 
Ghangrekar M. M., Asolekar S. R. and Joshi S. G. (2005) Characteristics of sludge developed under different loading conditions during UASB reactor start-up and granulation. Water Res., 39, 1123-1133.

Goncalves I. C. G., Penha S., Matos M., Santos A. R., Franco F. and Pinheiro H. M. (2005) Evaluation of an integrated anaerobic/aerobic SBR system for the treatment of wool dyeing effluents. Biodegradation, 16, 81-89.

Ho K. L., Chen Y. Y., Lin B. and Lee D. J. (2010) Degrading high-strength phenol using aerobic granular sludge. Appl. Microbiol. and Biotechnol., 85(6), 2009-2015.

Ibrahim Z., Amin M. F. M., Yahya A., Aris A., Umor N. A., Muda K. and Sofian N. S. (2009) Characterisation of microbial flocs formed from raw textile wastewater in aerobic biofilm reactor (ABR). Water Sci. and Technol., 60(3), 683-688.

Isik M. and Sponza D. T. (2008) Anaerobic/aerobic treatment of a simulated textile wastewater. Sep. and Purif. Technol., 60, 64-72.

Jang A., Yoon Y. H., Kim I. S., Kim K. S. and Bishop P. L. (2003) Characterization and evaluation of aerobic granules in sequencing batch reactor. J. of Biotechnol., 105, 71-82.

Lens P. N. L., Klijn R., van Lier J. B. and Lettinga G. (2003) Effect of specific gas loading rate on thermophilic $\left(55^{\circ} \mathrm{C}\right)$ acidifying $(\mathrm{pH} 6)$ and sulfate reducing granular sludge reactors. Water Res., 37, 1033-1047.

Linlin H., Jianlong W., Xianghua W. and Yi Q. (2005) The formation and characteristics of aerobic granules in sequencing batch reactor (SBR) by seeding anaerobic granules. Proc. Biochem., 40, 5-11.

Liu Y. and Tay J. H. (2002) The essential role of hydrodynamic shear force in the formation of biofilm and granular sludge. Water Res., 36, 1653-65.

Liu Y. and Tay J. H. (2004) State of the art biogranulation technology for wastewater treatment. Biotechnol. Adv., 22, 533-563.

Moosvi S. and Madamwar D. (2007) An integrated process for the treatment of CETP wastewater using coagulation, anaerobic and aerobic process. Bioresour. Technol., 98, 3384-3392.

Muda K., Aris A., Salim M. R., Ibrahim Z., Yahya A., van Loosdrecht M. C. M., Ahmad A. and Nawahwi M. Z. (2010) Development of granular sludge for textile wastewater treatment. Water Res., 44, 4341- 4350.

Ong S. A., Toorisaka E., Hirata M. and Hano T. (2008) Granular activated carbonbiofilm configured sequencing batch reactor treatment of C.I. acid orange 7. Dyes and Pigments, 76, 142-146.

Ong S. A., Toorisaka E., Hirata M. and Hano T. (2012) Decolorization of orange II using an anaerobic sequencing batch reactor with and without co-substrates. $J$. of Environ. Sci., 24(2), 291-296.

Qin L. and Liu Y. (2006) Aerobic granulation for organic carbon and nitrogen removal in alternating aerobic-anaerobic sequencing batch reactor. Chemosphere, 63, 926933.

Rongrong L., Lu X., Tian Q., Yang B. and Chen J. (2011) The performance evaluation of hybrid anaerobic baffled reactor for treatment of PVA-containing desizing wastewater. Desalination, 271, 287-294.

Shi X. Y., Sheng G. P., Li X. Y. and Yu H. Q. (2010) Operation of a sequencing batch reactor for cultivating autotrophic nitrifying granules. Biores. Technol., 101, 29602964. 
Smolders G. J. F., Klop J., van Loosdrecht M. C. M. and Heijnen J. J. (1995) A metabolic model of the biological phosphorus removal process. Effect of the sludge retention time. Biotechnol. and Bioeng., 48, 222-233.

Tay J. H., Liu Q. S. and Liu Y. (2002) Characteristics of aerobic granules grown on glucose and acetate in sequential aerobic sludge blanket reactors. Environ. Technol. 23, 931-936.

Tchobanoglous G., Burton F. L. and Stensel H. D. (2004) Wastewater engineering: treatment, disposal and reuse. ( $4^{\text {th }}$ Ed.). McGraw-Hill Companies Inc, New York, USA.

van der Zee F. P. and Villaverde S. (2005) Combined anaerobic-aerobic treatment of Azo dyes: A short review of bioreactor studies. Water Res., 39, 1425-1440.

Wang Q., Dua G. and Chena J. (2004) Aerobic granular sludge cultivated under the selective pressure as a driving force. Proc. Biochem., 39, 557-563.

Weber S. D., Ludwig W., Schleifer K. H. and Fried J. (2007) Microbial composition and structure of aerobic granular sewage biofilms. Appl. and Environ. Microbiol., 62336240.

Wu C. Y., Peng Y. Z., Wang S. Y. and Ma Y. (2010) Enhanced biological phosphorus removal by granular sludge: From macro- to micro-scale. Wat. Res., 44, 807-814.

Zheng Y. M., Yu H. Q. and Sheng G. P. (2005) Physical and chemical characteristics of granular activated sludge from a sequencing batch airlift reactor. Proc. Biochem., 40, 645-650.

Zhu L., Xu X., Luo W., Cao D. and Yang Y. (2007) Formation and microbial community analysis of chloroanilines-degrading aerobic granules in the sequencing airlift bioreactor. J. of Appl. Microbiol., 60, 683-688. 